\title{
Service Learning And Community-Based Partnerships: A Model For Teaching Macro Practice Social Work
}

Monica Nandan, University of Missouri-Kansas City, USA

Patricia Scott, University of Missouri-Kansas City, USA

\begin{abstract}
This article describes an innovative project that combined service learning and community-based partnerships to teach macro practice skills to social work students and citizenship skills to primary school students. The partners, a small social work program, several primary schools, and an internationally recognized civic engagement program, coordinated the project from 2003 to 2007. A formative evaluation of the project indicated that both primary school and social work students benefited from the experience. In particular, the project helped social work students develop a wide range of macro practice skills which, according to research, many graduates fail to acquire. In fact, students used knowledge and skills from all ten competency areas listed in the Council on Social Work Education's (2008) Educational Policy and Accreditation Standards. The authors conclude that social work programs need to provide students with macro-focused, community-based, supplemental experiences, similar to this project, if programs hope to meet CSWE accreditation standards.
\end{abstract}

Keywords: Service-learning; macro practice skills; citizenship skills; empowerment; formative evaluation

\section{INTRODUCTION}

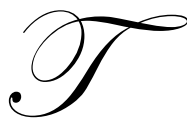

he Council on Social Work Education's 2008 Educational Policy and Accreditation Standards require generalist social work programs to design competency-based curricula that ensure student mastery of core competencies across all practice levels (individuals, families, groups, organizations, and communities) (CSWE, 2008). However, research suggests that social work programs may encounter problems demonstrating student mastery of macro practice skills. Available research indicates that social work students resist learning macro practice skills (Koerin, Reeves, \& Rosenblum, 2000) and most field practicum sites offer students few macro practice opportunities (Butler and Coleman, 2000; Koerin et al., 2000; Miller, Tice, \& Harnek Hall, 2008; Weiss, Gal, \& Cnaan, 2004). As a result, many social work graduates feel ill-prepared to work with larger systems (Miller et al., 2008). However, when students are given "hands-on" experiences that require them to develop and use macro skills and knowledge, students not only demonstrate macro practice skills, they develop an appreciation for macro practice and develop a sense of personal empowerment. ${ }^{i}$ Moreover, limited research suggests these types of experiential approaches may bolster students' use of macro practice skills after graduation (Anderson \& Harris, 2005; Butler \& Coleman, 1997; Rocha, 2000).

This article describes an innovative project that combined service-learning and community-based partnerships to teach community-organizing skills to social work students and citizenship skills to primary school children. The partners included a small Midwestern undergraduate social work program, several elementary schools, and an internationally known civic engagement program-Public Achievement. 


\section{SERVICE-LEARNING AND COMMUNITY-BASED PARTNERSHIPS}

\section{Service-learning}

The National Service-Learning Clearinghouse (2004) defines service-learning (SL) as "a teaching and learning strategy that integrates meaningful community service with instructions and reflection to enrich the learning experience, teach civic responsibility, and strengthen communities" (Welcome to Service-learning section, para. 1). Campus Compact (2009), "a national coalition of more than 1,190 colleges" dedicated to promoting "the civic purposes of higher education," reported that participating colleges and universities offered 24,271 SL courses during the 2007-2008 academic year (p. 7), and SL students "contributed \$5.7 billion and an estimated 282 million hours of service to their communities" (p. 2). Similarly, approximately $32 \%$ of public schools offered service-learning opportunities and 64\% organized community service activities for K-12 students (Skinner \& Chapman, 1999).

SL paradigms fall along a continuum from charity to social justice (Morton, 1995). Morton defined "charity" as "giving of the self, expecting nothing in return, and with no expectation" of any lasting impact (p. 20). In contrast, the social justice paradigm involves "speaking to others with a powerful voice" in an attempt to promote social change (p. 20). Educators who ascribe to the social justice paradigm believe SL experiences should sensitize and equip students to address social and economic injustice. They criticize SL "charity" courses as nothing more than a "glorified welfare system" (Robinson, 2000, p. 607) and "an exercise in patronization" (Pompa, 2002, p. 68).

The origins of SL lie "deep ... [within] the history of American democracy and higher education" (Zieren \& Stoddard, 2004, p. 23). University-sponsored SL started in Colonial America, when universities worked to improve literacy and develop a democratic informed electorate. SL expanded after Congress passed the Morrill Land Grant College Act in 1862, which established public universities whose mission focused on practical, applied learning. Although its use in higher education has fluctuated since its beginnings, SL has re-emerged at various points in history. For example, during the Progressive Era, many universities and service-learning students collaborated with local settlement houses to address serious community issues (Zieren \& Stoddard, 2004). Currently, SL is enjoying a renaissance in higher education, which many attribute to Ernest Boyer's influential 1990 publication, Scholarship Reconsidered: Priorities of the Professoriate. In this publication, Boyer urged the professoriate to make their scholarship relevant to contemporary life and use it to solve societal problems (Phillips, 2007).

SL is linked primarily to two educational theorists: John Dewey and Paolo Freire. Based on his theory of learning, Dewey believed students needed to address real problems, engage in collaborative problem-solving, experiment with solutions, and reflect upon the learning process to grow intellectually (Chambers, 2009). David Kolb expanded on Dewey's ideas about learning and defined learning as "the process whereby knowledge is created through the transformation of experience" (Kolb, Boyatzis, \& Mainemelis, 2001, p. 228). Theoretically, SL provides the experiential environment needed for transformational learning.

Educators who embrace a social justice paradigm attribute their SL approach to Paulo Freire and his notions of libratory education and critical pedagogy. According to Freire (1970), education is not neutral. Educators can indoctrinate students to conform to the status quo and maintain "cultures of silence," or help learners develop "critical consciousness" about prevailing inequities and impel them to work for social transformation (Freire, 1970).

Regardless of the paradigm, studies generally find that SL benefits students' learning and development. Researchers have conducted dozens of studies examining service-learning outcomes in both college and primary school students. Astin and Sax (1998), for example, measured community service outcomes for 3450 undergraduate students who participated in SL courses and concluded, "Participating in service during the undergraduate years substantially enhances the student's academic development, life skill development, and sense of civic responsibility" (p. 251). Novak, Markey, and Allen (2007) analyzed nine studies that compared student learning in courses with and without a SL component and found, "The addition of a service learning component" increased learning about 53\% (p. 149). Eyler, Giles, Stenson, and Gray (2001) reviewed SL research and concluded SL positively influenced students' personal and moral development, leadership and communication skills, cultural and racial understanding, 
sense of social responsibility and citizenship skills, commitment to service, academic learning, and ability to apply learned material to the "real world."

Research on SL with primary school students also yields positive results. Morgan and Streb (2001) studied 200 high school students from 10 schools involved in SL activities. They found that students who felt some degree of ownership over their SL projects experienced an enhanced sense of self-concept, an increased level of political engagement, and much greater tolerance for diversity. In the same vein, Waldstein's and Reiher's (2001) two-year study of 800 ninth graders revealed that students who were active in a variety of SL activities were more likely to develop and demonstrate positive personal and moral development as well as an increased sense of civic and social responsibility.

Although SL would seem to be "a natural fit for social work education," social work is a relative newcomer to this pedagogical approach (Rocha, 2000, p. 54). Lemieux and Allen (2007) indicated that very few social work educators integrate SL into their courses, which they attributed to two mistaken beliefs:

1. Many social work educators believe that field education is a form of SL. As Williams, King, and Koob (2002) note, SL focuses on community service and public works, not professional skill development, which is generally the focus of field pracitcum education.

2. Many social work educators believe that students' practicum experiences sufficiently prepare them for practice across system levels. Unfortunately, evidence suggests that most agencies cannot provide students with the breadth and depth of community practice experience needed to master macro practice competencies. According to Butler and Coleman (1997), "Most agencies fail to validate macro practice tasks as worthy aspects of workers' defined responsibilities, while the individual workers serving as field instructors possess neither the competence nor the confidence to model and teach macro level practice responses" (p. 65). Koerin et al. (2000), for example, studied students' field experiences and found that approximately $20 \%$ of students reported no practicum-related experiences with larger systems (e.g., organizations or communities). Moreover, the remaining students reported only limited macro experience, primarily in three areas: "agency assessment," "advocacy on behalf of individual clients," and "interviews with agency administrators." Miller et al. (2008) noted similar results and concluded, "The larger the client system the lower the level of experience among students" (p. 82).

Despite social work's newcomer status, some social work educators have incorporated SL as a component in macro practice courses and uniformly report positive results (Anderson \& Harris, 2005; Butler \& Coleman, 1997; Droppa, 2007; Johnson, 2010; Nadel, 2007; Richter-Hauk \& Arias, 2008; Rocha, 2000; Sather, Carlson, \& Weitz, 2007; Williams et al., 2002). Rocha (2000), for example, measured student values, competency, and activity levels between two groups of social work graduates: students who completed social work policy courses with communitybased, SL components and those who took traditional, classroom-based, policy classes. Although both groups valued policy practice equally after completing the classes, students in the experiential group were significantly more likely to "perceive themselves as competant policy practitioners and to perform policy-related activities after graduation" (p. 53).

Although the impact of SL on social work student skill development appears promising, most of the literature is anecdotal. Those few researchers who systematically measured outcomes incorporated weak research designs and methodology (Lemieux \& Allen, 2007). Consequently, no definitive conclusions can be drawn.

\section{Community-Based Partnerships}

Successful SL courses require instructors to develop and sustain relationships with community agencies. University-community partnerships share a parallel history with SL. The Morrill Act (1862) led to many universitycommunity partnerships and like SL, their popularity dramatically increased during the Progressive Era. In fact, Hull House partnered with the University of Chicago to address "the effects of industrialization and urbanization" on Chicago's low-income and immigrant population (Martin, Smith, \& Phillips, 2005, p. 4). Finally, like SL, university-community partnerships underwent a recent renaissance after the U.S. Department of Housing and Urban 
Development (HUD) created the Office of University Partnerships in 1994. Its mission was to revitalize local communities by encouraging and funding university-community partnership projects.

The literature indicates that university-community partnerships are sometimes difficult to forge. Johnson, Butterfield, and Soska (2005) indicated that community agencies often view university collaborations with suspicion because of previous unsuccessful "'ivory-tower' encounters" (p. 8). Once formed, various forces can strain university-community partnerships including issues of power and control, financial misunderstandings, cultural differences, lack of indigenous leadership, scheduling conflicts, and the time needed to sustain collaborations (Fogel \& Cook, 2010). Potential partners should be closely scrutinized to identify their strengths and potential weaknesses. The authors of this article were fortunate to partner with a local chapter of Public Achievement (PA), a program sponsored by a local community foundation and developed by the Center for Democracy and Citizenship in Minnesota. The Center's staff has been forging successful community partnerships since 1990. Their support and expertise were invaluable to building successful partnerships with local primary schools and launching the PA project.

\section{Center for Democracy and Citizenship and Public Achievement}

Public Achievement (PA) is one of several programs developed by the Center for Democracy and Citizenship designed to de-professionalize politics, promote democracy and "citizen ownership" of communities, and empower youth to seek solutions to community problems (Boyte, 2005, p. 541). It evolved from focus group interviews with hundreds of young people who bemoaned their inability to address community problems (Public Achievement [PA], 2004a). Today, PA is an internationally recognized, award-winning model to build youth citizenship and currently, operates in sites across the United States and in 20 countries including Northern Ireland, Turkey, the Balkans, and the West Bank and Gaza (PA, 2004c).

PA is heavily influenced by John Dewey's concept of the "community school." According to Dewey, schools have a "potent civic" responsibility - they should mobilize citizens to solve community problems and teach students how to be engaged, democratic citizens (Saltmarsh, 2008, p. 63). Dewey, who was heavily influenced by Jane Addams' work at Hull House, wrote: "What we want to see is the school, every public school, doing something of the same sort of work that is now being done by a settlement house" (as cited in Saltmarsh, 2008, p. 63). He felt the community school should actively engage children "both intellectually and morally" in solving community problems, to "foster cooperation and creative problem-solving among students", to engage in collective selfdetermination, to encourage students to "work and deliberate together", and to practice democratic principles (Saltmarsh, 2008, p. 64).

Public Achievement embraces all of these goals. Its mission includes encouraging community involvement; creating an empowering student environment; helping students develop and use political skills such as public speaking, active listening, conflict resolution, negotiation, and organizing; and helping participants understand the practical application of power, democracy, diversity, interests and citizenship (Kunkel, Johnson, Bakke, \& Miller, 2001). The core elements of PA's civic engagement model consist of 1) youth teams; 2) team projects; 3) team coaches; 4) coach coordinators; and 5) site coordinators (PA, 2004b). Teams consist of school children who volunteer to participate in the program. The children are divided into small groups of six to eight members based on their interests, and each team is assigned a coach who usually meets with his/her group weekly for about one hour.

Coaches are usually university, SL students who work closely with their assigned teams. Before meeting their groups, coaches receive training on how "to act like community organizers in schools" (Boyte \& Fretz, 2010, p. 75). Once trained, coaches work with their teams to develop a safe, democratic, empowering group environment; help teams identify, design, and implement projects that contribute to the public good; teach team members key democratic concepts; and provide support to team members. In order to foster collective self-determination among students, team members take turns leading meetings with help from their coach. Indeed, coaches are trained to "work with", not "do for" their teams. Consequently, team members must rely on one another to accomplish project tasks. 
To identify projects, teams discuss a wide range of local issues and select one topic to investigate further. Once researched, teams design and implement their projects by creating goals, an action plan, and an evaluation plan. Throughout the process, coaches help team members reflect on their activities within a sociopolitical context. Through a reflexive process of trial, some error, and ample reflection, team members implement, evaluate, and revise action plans based on feedback. Coaches also introduce important concepts like "democracy," "citizenship," "power," "interests," "diversity," "public," and "freedom" into group discussion and help team members develop political skills like "power mapping," conflict resolution and negotiation. Based on team members' interests, projects can range from removing soda from a school's vending machines to preventing animal cruelty, gang violence, or teenage pregnancy.

Because coaches are often inexperienced students or lay community members, every PA project assigns a coach coordinator who supervises, supports, and guides coaches. Ideally, the coach coordinator should also help SL students connect their community experience to course objectives and coordinate PA activities with the site coordinator. Site coordinators work to "integrate PA into the site culture, coordinate logistics, help teams continue their work outside of formal PA meetings, and help make PA's work visible" (PA, 2004b, Site Elements section, para. 2). They also serve as liaisons and are a vital link between the schools and their outside partners.

Many evaluations have been conducted on PA. One of the most comprehensive was conducted during the 2005-2006 academic year and used a mixed method approach to examine satisfaction, outcomes, and impact at eleven PA sites. Evaluation methods included observation, focus groups, surveys, and interviews with key personnel (i.e., principals and site and coach coordinators). In brief, the evaluation indicated that participating students developed teamwork, collaborative, and problem-solving skills, along with a greater sense of civic mindedness and self-confidence (RMC Research Corporation, 2006).

\section{PUBLIC ACHIEVEMENT PROJECT}

The authors' involvement in this project began when a representative from the local community foundation that sponsored Public Achievement approached the community practice course instructor about forming a partnership to implement Public Achievement in the local schools. Next, the instructor and PA representative approached several area schools. Eventually, they recruited three schools (two private and one public) to participate in Public Achievement and two teachers and one parent volunteer to serve as site coordinators. The community practice instructor served as the coach coordinator. The partnership started in fall 2003 and continued over the next four years until the community practice instructor moved from the area. Over the four-year period, 88 fifth to eighth grade students from the three schools participated in Public Achievement, and 53 social work students served as coaches.

Social work students were required to participate in the PA Project as part of the community practice course. Initially, students received the standard three credits for the semester-long community practice course, but because of the required time and commitment, the course instructor added a one-credit SL lab to the course, which was invaluable to getting social work student "buy-in."

At the beginning of each fall semester, each school's site coordinator organized interested school children into teams. Meanwhile, the PA coordinator and the community practice instructor (i.e., coach coordinator) trained the social work student coaches in three, four-hour training sessions. Training topics included developing and maintaining a collaborative group culture; identifying issues for potential projects; assessing community problems and developing strategies to address root causes; understanding power and politics; forming coalitions; and taking public action. The social work program also provided students with additional training on facilitating children's groups. Once trained, social work coaches met weekly with their teams for the remainder of the semester (about 12 weeks).

After each team meeting, coaches met with the site coordinator to debrief and problem-solve group-related issues. Common issues included inappropriate behavior in group sessions, failure to complete homework assignments, and structural barriers (e.g., consent to take team members off campus). Coaches also debriefed weekly with the coach coordinator during the community practice class. The instructor started class by discussing 
coaches' experiences and problem-solving issues before proceeding with that week's topic. Social work students also processed their experiences in their weekly journals, which was how the instructor evaluated students. Coaches were asked to detail their group's activities, identify the citizenship and community organization skills used by students and coaches respectively, and apply community practice concepts and principles to their PA experiences.

\section{Project Evaluation}

The community practice instructor, in consultation with the PA coordinator, site coordinators, and school principals, conducted a formative evaluation during the program's fourth year of operation. The instructor/evaluator adopted a "utilization-focused" approach to the evaluation (Patton, 2008). Its purpose was to identify the project's strengths and weaknesses, rectify implementation problems, ascertain participants' perspectives, and identify ways to improve the program. All primary users of the evaluation were involved in its design and implementation in order to foster "ownership of the evaluation purpose and findings (Patton, 2008, p. 38). The authors utilized a mixed-method approach (naturalistic and survey designs) and data collection techniques (qualitative and quantitative) to answer the following questions:

1. What were the experiences of social work student coaches and children participating in the PA project?

2. How did social work coaches rate the overall effectiveness of PA as a mechanism to teach citizenship skills?

\section{Instruments}

With partner assistance, the community practice instructor constructed two questionnaires: one for the school children and one for the coaches. Both instruments were administered at the end of the fall semester. The school children completed a 24-item questionnaire, which was orally administered by two trained social work students, who met with each child, read each question and then recorded his or her response. Questions were grouped into three categories: (1) overall satisfaction with PA; (2) preparedness of and satisfaction with coaches; and (3) skills learned through PA participation. Because of their age, school students answered dichotomous questions (yes-no) and then were asked to explain their response.

The coaches' questionnaire consisted of 40, five-point likert questions. After each question, coaches were asked to expound upon their numerical response. Questions were designed to assess: (1) coaches' perception of PA processes; (2) coaches' experiences as community organizers; (3) coaches' evaluation of the structures and support available in the school system; (4) skills and concepts that coaches developed/refined through PA participation; and (5) coaches' perspective on the citizenship-based skills learned by school students.

\section{RESULTS}

\section{Children's perspectives}

\section{Overall Satisfaction with PA}

Approximately $84 \%$ of the 37 student participants were very satisfied or satisfied with their PA experience. The same percentage believed their projects benefited the community, and $76 \%$ enjoyed the youth-driven nature of PA. The children's written responses supported the quantitative data. In short, students generally felt a greater sense of empowerment and self-efficacy as a result of their PA experience. As one sixth grade student wrote: "Kids can do a lot."

\section{Preparedness of and Satisfaction with Coaches}

Approximately $87 \%$ of the students praised their coach's meeting preparation, and nearly $76 \%$ believed their coach's guidance was instrumental to accomplishing their team goal. Overall, $73 \%$ of students expressed satisfaction with their coaches most of the time. One seventh grader commented, "They helped us do things we didn't know how to do." Students particularly appreciated their coaches' "technical skills and abilities," their ability to relate to their age group, their role as advisors and partners rather than "group leaders," and their ability to 
“explain relevant citizenship-oriented concepts," and "model interpersonal skills." An eighth grader captured these sentiments by stating, "They were very caring and supportive and listened to our ideas."

\section{Skills Learned through Participation in PA}

Interestingly, over $96 \%$ of the student respondents thought they would use the skills learned through PA in the future, and over $83 \%$ believed their PA experience helped them improve academically. Students identified "teamwork," "effective communication," and a sense "self-efficacy" as the top three skills they learned and refined during PA meetings. As stated by one eighth grader, "I learned how to communicate with others and how to work together." Approximately $92 \%$ of the students believed most students in their school would benefit if they participated in PA.

\section{Coaches' Perspectives of PA and Its Support Structures}

Overall, coaches were most satisfied with the coordination between the social work program and the local schools, the PA training manual, and the weekly debriefings; however, they were least satisfied with the schools' support for the PA program (see Table 1). Many coaches believed more should be done to involve teachers and the school principals, who sometimes inadvertently undermined the project. For example, coaches sometimes complained that teachers failed to give children class time to complete PA-related assignments. Coaches were particularly dissatisfied with the school principals, who many coaches described as unfriendly. Coaches also complained about school policies that interfered with students' projects (e.g., regulations about transporting children off school property).

Table 1: Evaluation of PA Structures and Support System by Coaches $(\mathrm{N}=13)$

\begin{tabular}{|l|c|}
\hline \multicolumn{1}{|c|}{ Structure and Support Categories } & Percent \\
\hline Helpfulness of site coordinator & 84.7 \\
\hline Helpfulness of principals & 15.4 \\
\hline Effectiveness of PA training for conducting weekly meetings & 84.6 \\
\hline Usefulness of PA training manuals & 92.3 \\
\hline Helpfulness of weekly debriefing sessions with coaches & 84.6 \\
\hline Conducive environment to conduct meetings in schools & 61.6 \\
\hline Support offered by schools to conduct PA groups and complete PA projects & 61.6 \\
\hline Quality of coordination between institutions involved in PA & 92.4 \\
\hline
\end{tabular}

* Percentage reflects ratings marked "greatly" and "moderately" on a five-point likert-scale.

\section{Coaches' Perception of School Students' Skill Development}

Table 2 summarizes coaches' ratings of the citizenship skills developed by school students in their respective PA groups. After only one semester, children regularly demonstrated various civic engagement skills (e.g., accountability, initiative, leadership) although they still needed additional time to master them. Nonetheless, certain concepts proved difficult for the children to understand and apply, especially "power and power mapping" and the distinction between "civics, community service, and public works".

Table 2: Coaches Rating of Skills Learned by Student Team Members (N=13)

\begin{tabular}{|l|c|}
\hline \multicolumn{1}{|c|}{ Skills Categories } & Percent* \\
\hline Extent to which students incorporated news items and research into PA meetings & 41.6 \\
\hline PA projects assisted students to learn about citizenship & 61.6 \\
\hline Students demonstrated democratic leadership skills in meetings & 46.2 \\
\hline Students demonstrated accountability and responsibility in meetings & 61.6 \\
\hline Students understood and applied power and power-mapping concepts & 30.8 \\
\hline Students discerned difference between issues and projects. & 61.6 \\
\hline Students demonstrated problem-solving abilities & 50 \\
\hline Students distinguished between civics, community service and public works & 23.1 \\
\hline Students worked on issues with a diverse group & 69.3 \\
\hline Students' willingness to take initiative & 69.2 \\
\hline
\end{tabular}

*Percentage reflects ratings marked greatly and moderately on a five-point likert-scale. 
Benefits of PA for Learning Macro Practice Skills

Coaches uniformly believed PA helped them develop and refine a variety of macro practice skills including leadership; time management; creativity; goal setting; use of self; conflict management; policy analysis; engagement and assessment; networking; agenda setting; planning; teambuilding; active listening; negotiation; creating, implementing, and evaluating action plans; interviewing; group facilitation; group empowerment; and effective communication skills. Many of these are skills community organizers rate as especially important (Garcia, Mizrahi, \& Bayne-Smith, 2010). Coaches also struggled with power-related concepts and skills and found them difficult to teach to their group members.

\section{CONSIDERATIONS AND RECOMMENDATIONS}

The literature clearly suggests the need for social work educators to provide supplemental, communitybased experiences to help students master macro practice competencies. This article discussed the use of a SL lab and CBP as one possible approach.

This project was unique in many ways. First, the social work student coaches learned macro practice skills in a semester-long, service-learning lab attached to a classroom-based community practice course. Each year the community practice instructor scheduled the lab when coordinators, coaches, and youth were available. Unlike many SL courses that require students to squeeze SL into their limited free time, the scheduled lab helped social work students coordinate their various personal and academic responsibilities.

Second, students learned macro practice skills by teaching them to youth. While the PA curriculum used the language of "civic engagement," in effect, macro practice and civic engagements skills are quite similar. Moreover, research indicates one of the best ways to learn new material is to teach it to others (Falchikov, 2001). Peer teaching enhances active learning, critical thinking, leadership, and motivation--all of which facilitate learning. Student coaches agreed that teaching youth these skills was an effective way to learn and refine their own skills. Equally important, the PA experience made the community practice text "come alive" through praxis. Students were able to ground abstract principles, theories, and skills in practice by semester's end.

Third, unlike many community-based projects designed to build social work student skills, PA coaches developed a full spectrum of macro practice skills. Other projects designed to teach macro practice skills, often require educators to divide a project among student teams. Consequently, one team may only learn focus-group related skills, while another team may only do secondary data analysis. Although worthwhile, these limited experiences fail to help students develop the broad array of skills needed in social work practice.

Fourth, unlike most SL courses, all social work student coaches participated in a similar group work experience and consequently were able to collectively reflect and learn from one another's successes and frustrations. This provided a wonderful shared learning experience. Moreover, they also had the opportunity to reflect with both the community practice instructor and the site coordinator, each of whom provided different project-related perspectives.

Finally, the local chapter of PA, with its roots in the Center on Democracy and Citizenship, proved to be an ideal community partner in many ways. First, it helped forge partnerships with the local schools. As Sanders (2003) noted, although many school officials agree that "community involvement in schools is important" for community health and students' social capital, in practice many school systems are very isolated and often reject community solicitations (p. 163). Since the PA program had been adopted by primary schools across the United States and its curriculum used language familiar to schools (e.g., civic engagement), it eased schools' initial distrust. Second, although the PA curriculum focused on civic engagement, the values, knowledge, skills it emphasized coincided closely with the macro practice course content. In fact, the coaches' training manual listed Saul Alinsky's book Rules for Radicals and Jane Addams' Democracy \& Social Ethics as recommended reading. Third, the Center provided critical resources and support needed to build and maintain partnerships. The community practice instructor could not have implemented the SL project without these resources and the initiative of the local community foundation. 


\section{Recommendations}

Notwithstanding the benefits accrued to the university and school students by participating in the PA project, the partnership posed certain challenges. In this section, the authors identify the main challenges and offer recommendations.

\section{Cultural Differences}

As Bringle and Hatcher (2002) note, university-community partnerships are complex due to the many cultural differences between participating organizations. Project participants wrestled with these differences on occasion. For example, primary schools "are bureaucratically organized with distinct hierarchical roles, a clear division of labor, rigid work routines and a top-down decision-making structure" (Tsui, Edwards, \& Lopez-Real, 2009, p. 14). Conversely, universities represent a loosely coupled amalgam of disciplines that some have described as "organized anarchies" (Cohen, March, \& Olsen, 1972, p. 1). These structural differences can frequently lead to miscommunication and misunderstandings. Consequently, partners must work tirelessly to establish equitable, honest, mutually beneficial relationships and must communicate frequently (Benson, Harkavy, \& Puckett, 2000). They must share power, make joint decisions, exercise flexibility, and demonstrate mutual respect and understanding of each partner's context and needs. In order to attain this level of communication, partners must be willing to "storm" before they can develop and sustain mutually beneficial norms.

\section{Scheduling}

One of the major obstacles (and cultural differences) related to scheduling. Because of university-school scheduling differences, a) it was difficult to identify a common time to schedule PA group meetings; b) PA groups could only meet for 40-45 minutes instead of the recommended hour; and c) debriefing sessions after group meetings lasted only 10-15 minutes. It is important that partners keep an ongoing dialogue about time-related issues because they frequently cause problems.

Another time-related issue concerned the social work coaches' involvement in PA. Because of the University's semester scheduling system, social work coaches only participated in PA for one semester. Consequently, while coaches helped school students plan their projects, they often did not witness their fruition, which usually occurred the following semester. Therefore, it is recommended that partners find ways for social work students to participate over two consecutive semesters. One possible solution would be weave PA involvement and assignments into subsequent social work courses, especially practice, policy, or field seminar classes. It is worth noting that over the course of four years - at least one to two social work students volunteered to coach their groups each spring for no credit, which clearly demonstrates social work students' commitment to the PA project.

\section{Time Commitment}

Partners dedicated considerable time to PA planning and organization, which is an important consideration especially for non-tenured faculty. Prior to the fall semester, partners devoted approximately 40 hours pitching the project to prospective school principals, preparing and signing contracts that delineated partnership expectations, and meeting and training prospective site coordinators. Once school started, the partners devoted at least one hour per week troubleshooting issues. Therefore, partners should seriously consider the time commitment before entering into an agreement.

Organizational "Buy-in"

Although the participating school principals allowed PA into their schools, most principals failed to infuse the program into the school culture, which is important for recruiting and retaining committed students, program sustenance, and enhancing PA's long-term impact. For example, without encouragement from the principals, teachers resisted integrating the PA curriculum into their lessons plans. The authors recommend that partners spend 
considerable time planning how to integrate PA into the school environment. Fortunately, PA provides a variety of tools and resources to help facilitate this process.

Funding

During the planning process, the partners failed to consider the need for funds to help students implement their projects. Consequently, some projects were never launched for lack of funding and school support. It is strongly recommended that the university, schools, and PA coordinator work together to identify and allocate a small fund dedicated to project support.

\section{Evaluation}

Finally, this article presents the results of a formative evaluation that examined participants' satisfaction with PA projects and their perception of its effectiveness in teaching citizenship and macro practice skills. Clearly, with longitudinal research, one can more objectively gauge students' and coaches' learning outcomes, their skill development, and the project's long-term impact on the schools, school children, and social work students. Because implementation of PA is unique at each site, it would be difficult, and perhaps unwise, to group outcome data without ensuring program fidelity and controlling for student differentials across settings. Instead, the authors recommend future site evaluators employ a similar mixed-method approach to program evaluation, and over time, evaluators may be able to extrapolate patterns based on careful comparative analyses of cross-program findings (Patton, 2008).

\section{SUMMARY AND CONCLUSION}

Based on its revised Educational Policy and Accreditation Standards, CSWE (2008) now requires social work programs to demonstrate student mastery of core competencies across all system levels. However, the literature suggests that many social work students fail to acquire macro practice skills since most practicum agencies focus exclusively on micro and mezzo practice. Unless social work programs provide students with supplemental, macro-focused experiences, students will continue to graduate unprepared to address large system issues.

This article described an innovative project designed to teach macro practice skills to social work students and citizenship skills to school children using service-learning and community-based partnerships. Social work students enrolled in a community practice class taught small groups of school children macro practice skills using a civic engagement curriculum developed by the Center for Democracy and Citizenship. Student groups then used these skills to plan and executive sustainable projects designed to address community problems. A formative evaluation of the project indicated that participating school children learned a variety of important civic engagement skills, like teamwork, leadership, and self-efficacy; and social work students successfully learned, taught, and applied macro practice concepts and skills to larger systems. In fact, students applied knowledge and practice skills from all 10 competency areas listed in the 2008 EPAs, including advocacy, personal reflection of values and biases, supervision and consultation, professional roles and boundaries, ethical decision-making, critical thinking, effective oral and written communication, analysis and application of conceptual frameworks, person and environment, policy advocacy, empowerment of others, working with diversity, collaboration for effective policy action, program evaluation, leadership, and engagement, assessment, and intervention in larger systems (CSWE, 2008).

In conclusion, social work programs need to provide students with large system practice experiences beyond the traditional practicum and service-learning projects, like the Public Achievement project, may be one of many methods educators can use to provide these experiences.

\section{AUTHOR INFORMATION}

Monica Nandan, Ph.D., is an Associate Professor of Social Work, at the University of Missouri-Kansas City. Her current research interests include social entrepreneurship, program evaluation and transdisciplinary education. Her past research has been in the field of gerontology and health care. She has authored articles in these fields and conducted several national conference presentations on these topics. E-mail: nandanm@umkc.edu 
Patricia Scott, PhD is an assistant professor of social work at the University of Missouri - Kansas City. Her research interests include higher education instructional design and theory; curriculum theory and analysis; program development and evaluation; and transdisciplinary education. She is the author of several articles on compressed course scheduling. E-mail: scottpa@umkc.edu

\section{REFERENCES}

1. Astin, A.W., \& Sax, I. (1998). How undergraduates are affected by service participation. Journal of College Student Development, 39(3), 251-263.

2. Anderson, D. K., \& Harris, B. M. (2005). Teaching social welfare policy: A comparison of two pedagogical approaches. Journal of Social Work Education, 41(3), 511-526.

3. Benson, L., Harkavy, I., \& Puckett, J. (2000). An implementation revolution as a strategy for fulfilling the democratic promise of university-community partnerships: Penn-West Philadelphia as an experiment in progress. Nonprofit and Voluntary Sector Quarterly, 29(1), 24-45.

4. Boyer, E.L. (1990) Scholarship Reconsidered. Priorities of the Professoriate. Princeton, NJ: The Carnegie Foundation for the Advancement of Teaching. Retrieved from https://depts.washington.edu/gs630/Spring/Boyer.pdf

5. Boyte, H. C. (2005). Reframing democracy: Governance, civic agency, and politics. Public Administration Review, 65(5), 536-546.

6. Boyte, H. C., \& Fretz, E. (2010). Civic professionalism. Journal of Higher Education Outreach and Engagement, 14(2), 67-90.

7. Bringle, R. G., \& Hatcher, J. A. (2002). Campus-community partnerships: The terms of engagement. Journal of Social Issues, 58, 503-516.

8. Butler, S. S., \& Coleman, P. A. (1997). Raising our voices: A macro practice assignment. Journal of Teaching in Social Work, 15(2), 63-80.

9. Campus Compact. (2009). 2008 service statistics: Highlights and trends of campus compact's annual membership survey. Boston, MA: Author. Retrieved from http://www.compact.org/wpcontent/uploads/2009/10/2008-statistics1.pdf

10. Carey, L. (2007). Teaching macro practice: An experiential learning project. Journal of Teaching in Social Work, 27(1/2), 61-71. DOI: 10.1300/J067v27n01_04

11. Chambers, T. (2009). A continuum of approaches to service-learning within Canadian post-secondary education. Canadian Journal of Higher Education, 39(2), 77-100.

12. Cohen, M. D., March, J. G., \& Olsen, J. P. (1972). A garbage can model of organizational choice. Administrative Science Quarterly, 17(1), 1-25.

13. Council on Social Work Education . (2008). 2008 Educational policy and accreditation standards. Retrieved from http://www.cswe.org/File.aspx?id=13780

14. Droppa, D. C. (2007). Social welfare policy and services: Service learning through social policy projects in human service organizations. In M. Nadel, V. Majewski \& M. Sullivan-Cosetti (Eds.) Social work and service learning: Partnerships for social justice (pp. 93-106). Lanham, Maryland: Rowman \& Littlefield.

15. Eyler, J. S., Giles, D. E., Jr., Stenson, C. M., \& Gray, C. J. (2001). At a glance: What we know about the effects of service-learning on college students, faculty, institutions, and communities, 1993-2000 (3rd ed.). Nashville, TN: Vanderbilt University.

16. Fogel, S. J. and Cook, J. R. (2006). Considerations on the scholarship of engagement as an area of specialization for faculty. Journal of Social Work Education, 42(3), 595-606.

17. Falchikov, N. (2001). Learning together: Peer tutoring in higher education. New York: RoutledgeFalmer

18. Freire, P. (1970). Pedagogy of the oppressed. New York: Continuum.

19. Garcia, M. L., Mizrahi, T. \& Bayne-Smith, M. (2010). Education for interdisciplinary community collaboration and development: The components of a core curriculum by community practitioners. Journal of Teaching in Social Work, 30, 175-194. doi: 10.1080/08841231003705255

20. Johnson, M. A. (2010). Teaching macro practice through service learning using participatory photography. Journal of Community Practice, 18, 297-314. doi: 10.1080/10705422.2010.486961. 
21. Johnson-Butterfield, A. K., \& Soska, T. M. (2005). University-community partnerships: An introduction. In A. Johnson-Butterfield \& T. Soska (Eds.), University-Community Partnerships: Universities in Civic Engagement (1-12). Binghampton, NY: The Hawthorne Social Work Practice Press.

22. Koerin, B. B., Reeves, J. and Rosenblum, A. (2000). Macro-learning opportunities: What is really happening out there in field? Journal of Baccalaureate Social Work, 6(1), 109-121.

23. Kolb, D. A., Boyatzis, R. E., and Mainemelis, C. (2001). Experiential learning theory: Previous research and new directions. In R. Sternberg \& L. Zhang (Eds.), Perspectives on Thinking, Learning, and Cognitive Styles (227-248). Mahwah, NJ: Lawrence Erlbaum Associates.

24. Kunkel, J., Johnson, C., Bakke, H., \& Miller, J. (2001). Public achievement: Collaboration, action, and civic education. Public Achievement. Retrieved May 19, 2007 from http://www.publicachivement.org/pdf/articles-papers/NCSSchapter.pdf.

25. Lemieux, C. M., \& Allen, P. D. (2007). Service learning in social work education: The state of knowledge, pedagogical practicalities, and practice conumdrums. Journal of Social Work Education, 43(2) , 309-325

26. Martin, L. L., Smith, H., \& Phillips, W. (2005). Bridging 'Town \& Gown' through innovative universitycommunity partnerships. The Innovation Journal: The Public Section Innovation Journal, 10(2), 1-16. Retrieved from: http://www.innovation.cc/volumes-issues/martin-u-partner4final.pdf

27. Miller, S. E., Tice, C. J., \& Harnek Hall, D. M. (2008). The generalist model: Where do the micro and macro converge? Advances in Social Work, 9(2), 79-90.

28. Morgan, W. \& Streb, M. (2001). Building citizenship: How student voice in service-learning develops civic value. Social Science Quarterly, 82(1), 154-170.

29. Morton, K. (1995). The irony of service: charity, project and social change in service-learning. Michigan Journal of Community Service Learning, 2(1), 19-32. Retrieved from:

http://quod.lib.umich.edu/cgi/t/text/pagevieweridx?c=mjcsl;idno=3239521.0002.102; $\mathrm{cc}=$ mjcsl; view=image

30. Nadel, M. (2007). Populations-at-risk/immersion experience: Service learning at a summer camp. In M. Nadel, V. Majewski, \& M. Sullivan-Cosetti (Eds.) Social Work and Service Learning: Partnerships for Social Justice (133-145). Lanham, Maryland: Rowman \& Littlefield.

31. National Service-Learning Clearinghouse (2004). What is service-learning? Retrieved from http://www.servicelearning.org/what-is-service-learning.

32. Novak, J. M., Markey, V., \& Allen, M. (2007). Evaluating cognitive outcomes of service learning in higher education: A meta-analysis. Communication Research Reports, 24(2), 149-157. doi: 10.1080/08824090701304881

33. Patton, M. Q. (2008). Utilization-Focused Evaluation (4 ${ }^{\text {th }}$ ed.). Los Angeles: Sage

34. Phillips, A. (2007). Service learning and social work education. In M. Nadel, V. Majewski, \& M. SullivanCosetti (Eds.), Social work and service learning: Partnerships for social justice (3-20). Lanham, Maryland: Rowman \& Littlefield.

35. Pompa, L. (2002). Service-learning as crucible: Reflections on immersion, context, power, and transformation. Michigan Journal of Community Service Learning, 9(1), 67-76.

36. Public Achievement (2004a). Background. Retrieved from http://www.augsburg.edu/cdc/publicachievement/1_3 history.html

37. Public Achievement (2004b). Core elements. Retrieved from http://www.augsburg.edu/cdc/publicachievement/1_2_core.html

38. Public Achievement (2004c). Sites. Retrieved from http://www.augsburg.edu/cdc/publicachievement/1_4_sites.html

39. Richter-Hauk, R. \& Arias, J. (2008). Developing professional values: Campus and community perspectives on a social work partnership. New Directions for Adult and Continuing Education, 118, 31-36 doi: 10.1002/ace.293

40. RMC Research Corporation (2006). Evaluation report: Public Achievement [Prepared for: Center for Democracy and Citizenship]. Denver, CO: Author

41. Robinson, T. (2000a). Service learning as justice advocacy: Can political scientists do politics? PS: Political Science and Politics, 33(3), 605-612.

42. Rocha, C. J. (2000). Evaluating experiential teaching methods in a policy practice course: The case for service learning to increase political participation. Journal of Social Work Education, 36(1), 53-63

43. Saltmarsh, J. (2008). Why Dewey Matters. The Good Society, 17(2) , 63-68. 
44. Sanders, M. G. (2003). Community involvement in schools: From concept to practice. Education and Urban Society, 35(2), 161-180.

45. Sather, P., Carlson, P., \& Weitz, B. (2007). Research: Infusing service learning into research, social policy, and community-based practice. In M. Nadel, V. Majewski, \& M. Sullivan-Cosetti (Eds.) Social work and service learning: Partnerships for social justice (93-106). Lanham, Maryland: Rowman \& Littlefield.

46. Skinner, R., \& Chapman, C. (1999). Service-Learning and community service in K-12 public schools. Washington, D.C: U. S. Department of Education, National Center for Education. Retrieved from: http://nces.ed.gov/pubs99/1999043.pdf

47. Tsui, A. B., Edwards, G., \& Lopez-Real, F. (2009). Learning in school-university partnership: Sociocultural perspectives. New York: Routledge.

48. Waldstein, F. A., \& Reiher, T. C. (2001). Service-learning and students' personal and civic development. Journal of Experiential Education, 24, 7-13.

49. Weiss, I., Gal, J., \& Cnaan, R. A. (2004). Social work education as professional socialization: A study of the impact of social work education upon students' professional preferences. Journal of Social Service Research, 31, 13-32.

50. Williams, N. R., King, M., \& Koob, J. J. (2002). Social work students go to camp: The effects of service learning on perceived self-efficacy. Journal of Teaching in Social Work, 22 \{3/4), 55-70. doi: 10.1300/067v22n03_05

51. Zieren, G. R., \& Stoddard, P. H. (2004). The historical origins of service-learning in the nineteenth and twentieth centuries: The transplanted and indigenous traditions. In B. Speck \& H. Hoppe (Eds.), Servicelearning: history, theory, and issues (23-33). Westport, Conneticut: Praeger.

\section{ENDNOTE}

\footnotetext{
${ }^{\mathrm{i}}$ The authors use the terms macro and community practice interchangeably in this article, which include community organizing, community planning, community development, and policy practice.
} 


\section{NOTES}

